\title{
Herpes Simplex Virus-Stimulated $\gamma$-Interferon Production by Newborn Mononuclear Cells
}

\author{
ANTHONY R. HAYWARD, MARK HERBERGER, AND DAN SAUNDERS \\ Departments of Pediatrics and Obstetrics, the Barbara Davis Childhood Diabetes Center, University of Colorado \\ School of Medicine, Denver, Colorado 80262
}

\begin{abstract}
Blood mononuclear cells from newborns and from adults, immune or nonimmune to herpes simplex virus, were cultured with IL 2 and herpes simplex virus and the amount of $\gamma$-interferon in the supernatant measured after 3 days. The newborn and nonimmune adult cells made equivalent trace amounts of $\gamma$-interferon in cultures containing either herpes simplex virus or IL 2 alone and there was a 5- to 10-fold increase in cultures containing both. Experiments in which the Leu $\mathrm{11}^{+}$cells were either depleted or enriched suggest that this subset of natural killer cells is both necessary and sufficient for $\gamma$-interferon production in the absence of immune T cells. (Pediatr Res 20: 398-401, 1986)
\end{abstract}

\section{Abbreviations}

HSV, herpes simplex virus

NK, natural killer

MNC, mononuclear cells

HBSS, Hanks' balanced salt solution

Human newborns are susceptible to severe infections with HSV (1) and those who recover have low frequencies of HSV specific responder $\mathrm{T}$ cells in their blood (2). The frequency of HSV-responder $T$ cells in normal newborns is low (less than $\left.1: 10^{6}\right)(3)$ and host defense is thought to depend primarily on antibody passively acquired from the mother and on nonspecific effector mechanisms including the production of interferons and NK cells (4). Leukocyte (or $\alpha$ ) interferon is made in equivalent amounts by human newborn and adult blood MNC stimulated by HSV (5). Less is known of $\gamma$-interferon, which is made by $\mathrm{T}$ cells $(6,7)$ and NK cells $(8)$. This lymphokine has a wide range of biologic activities (9) including suppression of cell growth and herpes virus replication and the amplification of NK lysis of virus-infected target cells. Previous studies indicate that newborn blood MNC have a low frequency of T cells which make $\gamma$ interferon spontaneously (10) and that they release less $\gamma$-interferon in response to phytohemogglutinin $(11,12)$, Concanavalin A, or OKT 3 antibody (Ortho Diagnostic Systems, Raritan, NJ) (12) than adult MNC unless the newborn MNC are first irradiated (12) or, in Taylor \& Bryson's study (11), the newborn monocytes were replaced by adult monocytes. Phytohemogglutinin and Concanavalin A activate a wide range of cells so the existing data give no indication of the relative ability of newborn and adult NK cells to respond to a herpes virus stimulus. We

Received September 9, 1985; accepted December 24, 1985.

Correspondence Dr. Anthony R. Hayward, Department of Pediatrics, University of Colorado HSC, 4200 East Ninth Avenue, Denver, CO 80262.

This research was supported in part by NIH Grants HD 13733 and AI 1894 and a clinical research grant from the National Foundation, March of Dimes. Subject identification was possible through a GCRC Grant RR 0069. have therefore cultured newborn and adult MNC, either unfractionated or following depletion of the predominant NK cell subset, with HSV and with or without IL 2 and measured the amount of $\gamma$-interferon released into the supernatant.

\section{MATERIALS AND METHODS}

Blood samples. Newborn blood was obtained from the placental end of the cut cord of healthy newborn deliveries and adult blood from healthy volunteers. Blood samples were anticoagulated with $10 \mathrm{U} / \mathrm{ml}$ heparin and the red cells in the newborn samples were sedimented with a 30 -min incubation with $1.5 \%$ Hetastarch (Hespan, American Hospital Supply Corp, Irvine, CA). MNC were separated on Ficoll-Hypaque gradients and washed twice in HBSS before being adjusted to $10^{6} / \mathrm{ml}$ in RPMI 1640 medium supplemented with $40 \mu \mathrm{g} / \mathrm{ml}$ gentamicin and $10 \%$ human serum.

MNC were depleted of Leu $11^{+}$cells by complement mediated lysis using $8 \mu \mathrm{l}$ Leu 11b (Becton Dickinson Monoclonal Antibodies, Mountain View, CA) per $10^{7}$ cells and a $45-\mathrm{min}$ incubation at room temperature, followed by $45 \mathrm{~min}$ in a 1:6 dilution of complement (Low-tox-H rabbit complement, Cedarlane Labs, Ontario, Canada) as recommended (Becton Dickinson Source Book, section 4.31). This procedure killed about $20 \%$ of the $\mathrm{MNC}$ and subsequent staining with Leu 1 la indicated that over $80 \%$ of Leu $11^{+}$cells were killed. Depletion of monocytes was by adherence to Sephadex G 10 as described by Ly and Mishell (13). Enrichment of NK cells was by Percoll (Sigma Chemical Co, St. Louis, MO, made isotonic with $10 \%$ of $10 \times \mathrm{HBSS}$ ) density gradient centrifugation (14) with discontinuous steps (7 $\times 5 \%$, from 60 to $30 \%$ ). MNC depleted of adherent cells were resuspended in HBSS and loaded at the top of the gradient for 30 min centrifugation at room temperature at $550 \times \mathrm{g}$. Cells were counted after all the depletion/enrichment steps and readjusted to $10^{6} / \mathrm{ml}$.

Cell cultures with HSV or IL 2 were in Falcon 2056 tubes, loosely capped, in a $\mathrm{CO}_{2}$ incubator for 3 days, after which the cells were spun down and the supernatant recovered and kept frozen at $-20^{\circ} \mathrm{C}$ until assayed. The 3-day culture period was selected as optimal for $\gamma$-interferon production on the basis of the results of Pearlstein et al. (15).

HSV (Kos strain) was kindly provided by Dr. L. Pizer and grown in rabbit skin cells at confluence in Dulbecco's minimal essential medium with $2 \%$ fetal calf serum. Infected monolayers showing complete cytopathic effect were harvested and sonicated, the cell debris was spun down at $200 \times g$ for $10 \mathrm{~min}$. Virus was stored at $-70^{\circ} \mathrm{C}$ and contained $10^{7}$ plaque forming units $/ \mathrm{ml}$ by a plaque assay on rabbit skin cells.

IL 2 was purchased from AmGen (Thousand Oaks, CA), lots 103 at $2 \mathrm{U} / \mathrm{ng}$ and 104 at $10 \mathrm{U} / \mathrm{ng}$, and was diluted to $10 \mathrm{U} / \mathrm{ml}$ in RPMI 1640.

Gamma-interferon assay was by the double antibody radioimmunoassay (IMRX, Centocor Labs, Malvern, PA). The assay 
was calibrated with the standards provided. There was a linear relationship between the $\gamma$-interferon concentration and cpm of ${ }^{125} \mathrm{I}$ bound in all assays (correlation coefficient greater than 0.98 ). Gamma-interferon concentrations in the tissue culture supernatants were calculated by linear estimation using Abstat software (Anderson-Bell, Canon City, CO).

Cells were phenotyped by immunofluorescent staining with fluorescein conjugated Leu 11a (Becton Dickinson Monoclonal Antibodies, $5 \mu \mathrm{l} / 10^{6}$ cells) and phycoerythrin conjugated anti-IL 2 receptor antibody (no. 7647, Becton Dickinson Monoclonal Antibodies). The cells were washed three times in HBSS with $0.1 \%$ sodium azide and $0.1 \%$ bovine serum albumin and were fixed in $2 \%$ paraformaldehyde. Analysis was on a Coulter EPICS $\mathrm{C}$ using the Quadstat program.

\section{RESULTS}

Stimulation of $\gamma$-interferon production by $H S V$ and IL 2. In preliminary experiments the ability of different concentrations of IL 2 or HSV to elicit $\gamma$-interferon production by newborn MNC were compared. The results (Fig. 1) indicate that unstimulated newborn MNC do not make detectable amounts of $\gamma$ interferon in their first 3 days of culture and that in the presence of IL 2 alone small amounts (up to $10 \mathrm{U} / \mathrm{ml}$ ) of $\gamma$-interferon are detected in proportion to the IL 2 concentration. Newborn MNC cultures stimulated with live HSV alone made small amounts (mean $3 \mathrm{U} / \mathrm{ml}$ ) of $\gamma$-interferon without any $\mathrm{HSV}$ concentration relationship over the range tested. Combinations of HSV and IL 2 made more $\gamma$-interferon than either stimulus alone. On the basis of these results we selected $10 \mathrm{U} / \mathrm{ml}$ of IL 2 as a suboptimal concentration at which we could compare $\gamma$-interferon production by newborn and adult MNC in the presence of HSV. The resuts (Table 1) are consistent with those in Figure 1 and show that only MNC from immune donors made substantial amounts of $\gamma$-interferon (up to $110 \mathrm{U} / \mathrm{ml}$ ) in cultures stimulated with $\mathrm{HSV}$ alone. Cultures of nonimmune adult and newborn MNC made little $\gamma$-interferon in response to $\mathrm{HSV}$ or to $10 \mathrm{U} / \mathrm{ml}$ IL 2 but there was a synergistic effect with production of a mean of $53 \mathrm{U} / \mathrm{ml}$ in newborn cultures containing both IL 2 and 1 . In a separate series of experiments (not shown in Table 1) killed HSV was used with $10 \mathrm{U} / \mathrm{ml}$ of IL 2 as the stimulus for $\gamma$-interferon production by adult immune donor MNC. These cultures gave less $\gamma$-interferon (mean $54 \mathrm{U} / \mathrm{ml}$ ) than cultures using live HSV (mean $100 \mathrm{U} / \mathrm{ml}$ ). For subsequent experiments we used only the live virus preparations.

Gamma-interferon is known to be made by $T$ lymphocytes (7)

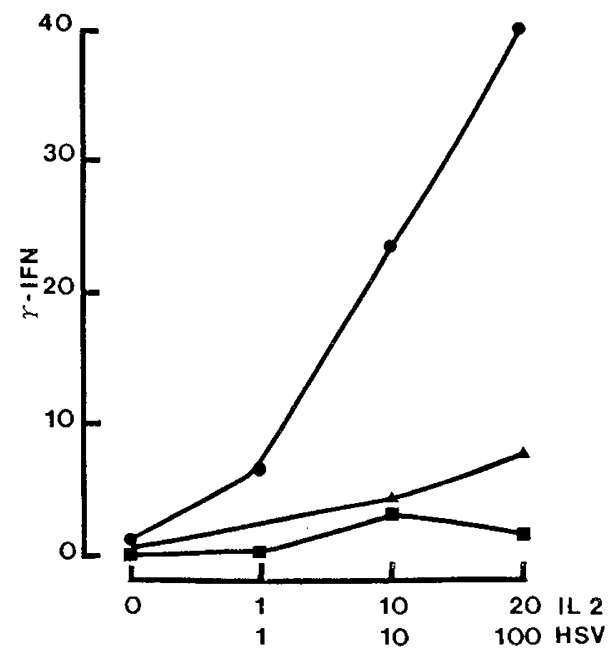

Fig. 1. In vitro $\gamma$-interferon production by $10^{6}$ newborn $\mathrm{MNC}$ stim-

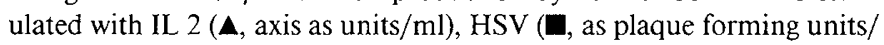
$\mathrm{ml} \times 10^{-4} / \mathrm{ml}$ ) or $(\bullet)$, with $10^{6}$ plaque forming units $\mathrm{HSV} / \mathrm{ml}+$ varying amounts of IL 2 .
Table 1. In vitro $\gamma$-interferon production by adult immune and nonimmune and healthy newborn donor $M N C$ as $U / \mathrm{ml}^{*}$

\begin{tabular}{lrrrrr}
\hline Donors & $\mathrm{n}$ & \multicolumn{1}{c}{0} & \multicolumn{1}{c}{ IL 2 } & \multicolumn{1}{c}{ HSV } & Both \\
\hline Immune & 5 & $2(1)$ & $28(5)$ & $106(6)$ & $105(6)$ \\
- Leu 11 & & $1(1)$ & $14(3)$ & $32(4)$ & $40(3)$ \\
-Adh & & $37(5)$ & $48(4)$ & $54(6)$ & $82(4)$ \\
& & & & & \\
Nonimmune & 2 & $1(1)$ & $10(3)$ & $8(2)$ & $72(12)$ \\
-Leu 11 & & $0.5(1)$ & $8(3)$ & $7(2)$ & $20(6)$ \\
-Adh & & $35(5)$ & $40(6)$ & $28(7)$ & $67(7)$ \\
& & & & & \\
Newborn & 6 & $1(1)$ & $3(1)$ & $3(1)$ & $53(2)$ \\
-Leu 11 & & $0(1)$ & $1(1)$ & $2(1)$ & $6(1)$ \\
-Adh & & $7(4)$ & $42(5)$ & $8(4)$ & $45(6)$ \\
\hline
\end{tabular}

$* 10^{6}$ cells were incubated for 3 days when supernatant $\gamma$-interferon was measured by radioimmunoassay. All cultures were in 1-ml volumes; IL 2 concentration $=10 \mathrm{U} / \mathrm{ml}, \mathrm{HSV}=10^{6} \mathrm{PFU} / \mathrm{ml}, n=$ number of samples assayed. - Leu $11=\mathrm{MNC}$ depleted of Leu $11^{+}$cells by incubation with Leu $1 \mathrm{lb}$ and Cedarlane Low Tox rabbit complement. - Adh $=$ MNC depleted of monocytes by passage over Sephadex G 10. Figures in parentheses $= \pm 1 \mathrm{SE}$ range.

and NK cells (8). We have previously shown that the frequency of herpes virus responder $T$ cells in newborn and adult nonimmune donors is very low ( $<1$ in $10^{6}$ and $1: 10^{5}$, respectively) so it was very unlikely that $\mathrm{T}$ cells were the origin of $\gamma$-interferon in our newborn cultures. To test the requirement for the Leu $11^{+}$ subset of NK cells, we selectively depleted adult and newborn MNC subsets with Leu $11 \mathrm{~b}$ and complement before stimulation with IL 2 and HSV.

Requirement for monocytes and Leu $11^{+}$cells for HSV + IL 2 stimulated $\gamma$-interferon production by nonimmune donors' $M N C$. Depletion of Leu $11^{+}$cells from the MNC reduced the amount of $\gamma$-interferon made in all HSV + IL 2 stimulated cultures. The reduction was proportionally greatest $(10$-fold $)$ in the newborn samples. To determine whether monocytes were necessary for $\gamma$ interferon production in response to HSV and IL 2 we depleted MNC preparations of adherent cells by passage over Sephadex G 10. Paradoxically, the $\gamma$-interferon production by these preparations was raised even without further stimulus and the addition of IL 2 alone gave maximal production.

Production of $\gamma$-interferon by enriched Leu $11^{+}$cells. The above results suggested that Leu $11^{+}$cells were necessary for $\gamma$-interferon production by nonimmune cells stimulated by HSV and IL 2. To determine whether Leu 11 cells would also be sufficient we enriched MNC for this fraction by Percoll density gradient centrifugation. The resulting fractions were stimulated with IL 2 + HSV for 3 days and the amount of $\gamma$-interferon in the supernatant measured. The results (Fig. 2) indicate that the fraction with the buoyant density of large granular lymphocytes (fraction 3, at $45 \%$ Percoll) made the maximum amount of $\gamma$ interferon, although the absolute amounts (mean $24 \pm 4 \mathrm{U} / \mathrm{ml}$ for three experiments) were lower than the mean of $53 \mathrm{U} / \mathrm{ml}$ obtained in cultures of comparable numbers of unseparated MNC.

Phenotype of cultured cells following stimulation. The above results suggested that Leu $11^{+}$cells were both necessary and sufficient for the in vitro production of $\gamma$-interferon by HSV + IL 2 stimulated nonimmune newborn or adult MNC. Since Leu $11^{+}$cells are reported to express an IL 2 receptor following exposure to IL 2 (16) we phenotyped the cells recovered from the cultures. The results (Table 2, column 1, unmanipulated cells) indicate that the antibody and complement treatment was indeed effective in reducing the percent of Leu $11^{+}$cells. Comparable low frequencies of Leu $11^{+}$cells were recovered from the cultures which were supplemented with IL 2 or HSV while the combination of IL $2+$ HSV increased the percentage of Leu $11^{+}$ but not IL $2 \mathrm{R}^{+}$cells. IL 2 receptor-positive T 3 cells were found 


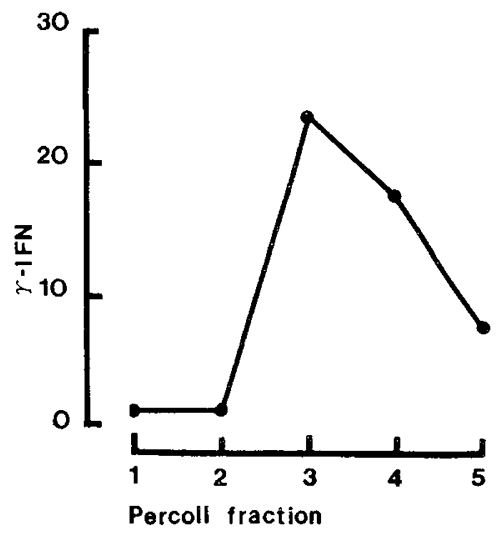

Fig. 2. In vitro $\gamma$-interferon production by Percoll density gradient separated fractions of newborn MNC stimulated with $10^{6}$ plaque forming units HSV $+10 \mathrm{U} / \mathrm{ml} \mathrm{IL} \mathrm{2.} \mathrm{Result} \mathrm{shown} \mathrm{is} \mathrm{representative} \mathrm{of} \mathrm{three}$ experiments with similar responses.

Table 2. Percent of Leu $11^{+}$cells before and after culture*

\begin{tabular}{llrrrr}
\hline \multicolumn{1}{c}{ Donor } & Treatment & \multicolumn{1}{c}{0} & IL 2 & HSV & Both \\
\hline Immune & None & 16 & 20 & 18 & 38 \\
& -Leu 11 & 3 & 4 & 9 & 35 \\
Nonimmune & None & 15 & 17 & 17 & 42 \\
& -Leu 11 & 4 & 3 & 5 & 39 \\
Newborn & None & 8 & 8 & 7 & 21 \\
& -Leu 11 & 1 & 2 & 3 & 21
\end{tabular}

* Results are the mean of three samples tested in each group. SEs $<12 \%$ of mean in all cases.

in MNC cultures from immune donors but not in cultures from nonimmune newborns or adults.

\section{DISCUSSION}

Our results extend previous observations by showing that HSV alone is a sufficient stimulus for the release of $2-10 \mathrm{U} / \mathrm{ml}$ of $\gamma-$ interferon by $10^{6} \mathrm{MNC}$ from nonimmune donors, whether newborn or adult. These amounts of $\gamma$-interferon are small compared with the $90-110 \mathrm{U} / \mathrm{ml}$ of $\gamma$-interferon made by $10^{6} \mathrm{MNC}$ from immune donors. The difference must in part result from the presence of HSV-specific T cells in the MNC from immune donors since these cells are known to release $\gamma$-interferon following activation (17). Antigen-activated $T$ cells also release IL 2 and to determine what effect this might have on $\gamma$-interferon production by newborn cells we added recombinant IL 2 to the cultures of newborn and adult nonimmune donors. In each case more $\gamma$-interferon was obtained in the IL 2 than in the HSVstimulated cultures, with a synergistic effect in cultures containing both. HSV alone was, in contrast, sufficient to induce maximal amounts of $\gamma$-interferon production by the immune donors' MNC, most probably because the antigen stimulus elicits the production of $1-5 \mathrm{U} / \mathrm{ml}$ of IL 2 (previous unpublished results).

The MNC subset manipulation experiments suggested that Leu $11^{+}$cells were necessary for $\gamma$-interferon production by the nonimmune cells. Whether Leu $11^{+}$cells are also sufficient for $\gamma$-interferon production is less certain in that the amounts of $\gamma$ interferon we recovered from large granular lymphocyte-enriched preparations were proportionally rather less than were made by unseparated cells. This difference may well be an artefact of the separation or culture conditions in that previous studies in which monocytes were added back to Percoll separated human large granular lymphocytes showed no requirement for monocytes for either $\alpha$ (14) or $\gamma$-interferon (6) production. Mouse spleen cells, in contrast, do appear to require the presence of macrophages for optimal $\gamma$-interferon production in response to IL 2 (18).

The Sephadex G 10 separations we performed to explore this possibility suggested that the predominant effect of adherent cells (newborn or adult) on $\gamma$-interferon production was suppressive: both background and IL 2 stimulated $\gamma$-interferon levels were higher after depletion of adherent cells. This monocyte-mediated $\gamma$-interferon suppression has been observed previously and was recently attributed to in vitro prostaglandin E synthesis (12). Presently available data suggest that monocytes are not necessary for $\gamma$-interferon synthesis by human MNC.

The percentage of Leu $11^{+}$cells in newborn and adult cultures was always higher in cultures that had been stimulated with IL $2+$ HSV than either alone. This increase was also found when Leu 11 cells were depleted from the cells before culture by antibody and complement. Possible explanations for the increase include rapid proliferation of a small remaining subset, or the induction of the Leu 11 antigen on previously negative cells under these culture conditions. Propidium iodide staining of the Leu $11^{+}$cells gave no indication that they had moved out of $G_{0}$ (Leibson PA, personal communication), so rapid proliferation seems unlikely. The possibility that the antigen is newly induced on cells during the culture period remains to be excluded.

The ability of IL 2 alone to induce $\gamma$-interferon release by MNC from mature animals has been reported previously (15, 18) and it complicates the interpretation of previous reports where HSV antigen was used to stimulate $\gamma$-interferon production. Green et al. (19), for example, found high levels of $\gamma$ interferon in the culture supernatants of nonimmune adult donors' MNC stimulated with UV inactivated HSV for $48 \mathrm{~h}$. Little $\gamma$-interferon was found in these cultures after 5 days' incubation where the cultures had been washed at $48 \mathrm{~h}$. Factors that may have interfered with these workers' detection of $\gamma$-interferon production by nonimmune donors MNC include the use of fetal calf serum as a medium supplement (this would tend to activate $\mathrm{T}$ cells nonspecifically and raise the background response), the use of inactivated virus and the intermediate washing step which would remove IL 2 .

Our observations suggest that newborn NK cells with the Leu $11^{+}$phenotype are, like adult cells (20), capable of recognizing HSV antigens and that their ability to make $\gamma$-interferon is limited not by intrinsic immaturity but by the availability of IL 2. While newborn T cells can make IL 2 in the same amounts as adult cells following nonspecific activation by mitogens (21) the frequency of HSV-responsive T cells at birth is less than $1: 10^{6}$ (3) and HSV antigen stimulation does not result in the release of IL 2. HSV-specific T cells, however, are unlikely to be responsible for the reduction in susceptibility to severe HSV infections which takes place in the first weeks of life as this occurs without the spontaneous development of HSV-specific immunity. Whether the generation of $T$ cells of other specificities as a result of environmental exposure provides cells which can be recruited into NK cell responses as bystanders and provide IL 2, or whether IL 2 is supplied by increasingly mature NK cells themselves (8) is not yet known.

\section{REFERENCES}

1. Nahmias AJ, Visintine AM 1977 Herpes simplex. In: Remington JS, Klein JO, eds Infectious Diseases of the Fetus and Newborn Infant. W.B. Saunders \& Co. Philadelphia, pp 156-170

2. Hayward AR, Herberger MJ, Groothuis J, Levin M 1984 Specific immunity after congenital or neonatal infection with cytomegalovirus or herpes simplex virus. J Immunol 133:2469-2473

3. Chilmonczyk B, Levin MJ, McDuffy R, Hayward AR 1985 Characterization of the human newborn response to herpes virus antigen. J Immunol 134:4184-4188

4. Kohl S, Loo LS, Gonik B 1984 Analysis in human neonates of defective antibody-dependent cellular cytotoxicity and natural killer cytotoxicity to herpes simplex virus-infected cells. J Infect Dis 150:14-19

5. Kohl S, Harmon MW 1983 Human neonatal leukocyte interferon production and natural killer cytotoxicity in response to herpes simplex virus. J Interferon Res 3:461-463 
6. Ratliff TL, MacDermott RP, Poepping NJ, Oakley DM, Shapiro A, Catalona WJ Production of gamma interferon by human $T$ and null cells and its regulation by macrophages. Cell Immunol 74:111-119

7. Cunningham AL, Merigan TC 1984 Leu- $3^{+}$T cells produce $\gamma$-interferon in patients with recurrent herpes labialis. J Immunol 132:197-202

8. Kasahara T, Djeu JY, Dougherty SF, Oppenheim JJ 1983 Capacity of human large granular lymphocytes (LGL) to produce multiple lymphokines: interleukin 2, interferon, and colony stimulating factor. J Immunol 131:23792385

9. Trinchieri G, Perussia B 1985 Immune interferon: a pleiotropic lymphokine with multiple effects. Immunol Today $6: 131-136$

10. Martinez-Maza O, Andersson U, Andersson J, Britton S, Deley M 1984 Spontaneous production of interferon- $\gamma$ in adult and newborn humans. J Immunol 132:251-255

11. Taylor S, Bryson YJ 1985 Impaired production of $\gamma$-interferon by newborn cells in vitro is due to a functionally immature macrophage. J Immunol 132:1493-1497

12. Wakasugi N, Virelizier JL, Arenzana-Seisdedos F, Rothhut B, Mencia Huerta JM, Russo-Marie F, Fiers W 1985 Defective IFN- $\gamma$ production in the human neonate. J Immunol 134:172-176

13. Ly IA, Mishell RI 1974 Separation of mouse spleen cells by passage through columns of sephadex G-10. J Immunol Methods 5:239-247

14. Djeu JY, Stocks N, Zoon K, Stanton GJ, Timonen T, Herberman RB 1982
Positive self regulation of cytotoxicity in human natural killer cells by production of interferon upon exposure to influenza and herpes viruses. $J$ Exp Med 156:1222-1234

15. Pearlstein KT, Palladino MA, Welte K, Vilcek J 1983 Purified human interleukin-2 enhances induction of immune interferon. Cell Immunol 80:1-9

16. Trinchieri G, Matsumoto-Kobayashi M, Clark SC, Seehra J, London L, Perussia B 1984 Response of resting human peripheral blood natural killer cells to interleukin. J Exp Med 160:1147-1169

17. Epstein LB, Gupta S 1981 Human T lymphocyte subset production of immune interferon. J Clin Immunol 1:186-194

18. Kawase I, Brooks CG, Kuribayashi K, Olabuenaga S, Newman W, Gillis S, Henney CS 1983 Interleukin 2 induces $\gamma$-interferon production: participation of macrophages and NK-like cells. J Immunol 131:288-292

19. Green JA, Yeh T-J, Overall JC 1981 Sequential production of IFN- $\gamma$ and immune-specific IFN- $\gamma$ by human mononuclear leukocytes exposed to herpes simplex virus. J Immunol 127:1192-1196

20. Bishop GA, Marlin SD, Schwartz SA, Glorioso JC 1984 Human natural killer cell recognition of herpes simplex virus type 1 glycoproteins: specificity analysis with the use of monoclonal antibodies and antigenic variants. $J$ Immunol 133:2206-2214

21. Hayward AR, Kurnick J 1981 Newborn T cell suppression: early appearance, maintenance in culture, and lack of growth factor suppression. J Immunol $126: 50-53$ 